\title{
BICHAS INAUGURAM A UTOPIA: RESISTÊNCIA HOMOERÓTICA NA LITERATURA LAMPIÔNICA
}

\section{QUEERS INAUGURATE UTOPIA: HOMOEROTIC RESISTANCE IN THE LITERATURE PUBLISHED IN THE BRAZILIAN NEWSPAPER LAMPIÃO DA ESQUINA}

Ricardo Afonso-Rocha'

André Luís Mitidieri²

\begin{abstract}
RESUMO: Com foco na coluna literária do jornal guei Lampiâo da Esquina, no período de 1978, ano de surgimento desse periódico, objetivamos investigar se a literatura nele publicada expressa, enquanto laço homossocial, o exercício da resistência homoerótica à "ditadura cis-hétero-militar brasileira". Os recortes extraídos do corpus literário permitem constituir os seguintes gestos de análise: 1) abre-se à interpretaçấo a possibilidade de ler a produçâo publicada no Lampiăo como ato de resistência ao regime ditatorial; 2) percebe-se a convolaçáo da palavra literária em estratégias jurídicas e nâo-jurídicas de contestaçăo/resistência; 3) identifica-se a rasura da pornografia autoritária, imposta pelo regime cis-hétero-militar; 4) delimita-se a tensăo do regime de cis-hétero-realidade, incitando a formaçăo de laços de homossocialidade. Utilizamos metodologia qualitativa, de caráter bibliográfico, para revisăo de literatura; bem como a técnica historiográfica de análise documental, para exame do jornal.
\end{abstract}

Palavras-chave: literatura homoerótica; Lampiâo da Esquina; direito de resistência; ditadura cis-hétero-militar brasileira.

ABSTRACT: Focusing on the literary column of the gay newspaper Lampiâo da Esquina, in the period of 1978, the year of the first publication of this journal, we aim to investigate whether the literature published in it expresses, as a homosocial tie, the exercise of homoerotic resistance to the Brazilian cis-hetero-military dictatorship. The cuttings extracted from the literary corpus allow us to constitute the following gestures of analysis: 1) opens to interpretation the possibility of reading the production published in Lampiâo as an act of resistance to the dictatorial regime; 2) the literary word is convoluted in legal and non-legal strategies of contestation / resistance; 3) the erasure of authoritarian pornography imposed by the cis-hetero-military regime is identified;

1 Mestrando em Letras na Universidade Estadual de Santa Cruz (UESC). Membro do grupo de pesquisa O espaço biográfico no horizonte da literatura homoerótica -GPBIOH. E-mail: rickwhoop22@gmail.com

2 Professor Titular de Literaturas Vernáculas no Curso de Letras da Universidade Estadual de Santa Cruz (UESC). Doutorado em Letras, área de concentraçăo em Teoria da Literatura, pela Pontifícia Universidade Católica do Rio Grande do Sul (PUCRS).E-mail: mitidierister@gmail.com 
4) the tension of the cis-hetero-reality regime is delimited, inciting the formation of homosociality bonds. We used a qualitative methodology, of bibliographical character, to review the literature, as well as the historiographic technique of documentary analysis, for examining the journal.

Keywords: homoerotic literature; Lampiâo da Esquina; right of resistance; brazilian cishetero-military dictatorship.

\section{UM LAMPIÃO FOI ACESSO NAS ESQUINAS DO BRASIL ${ }^{3}$}

Pretendendo investigar se a literatura publicada na coluna literária do jornal guei Lampiâo da Esquina expressa o exercício da resistência homoerótica à "ditadura cis-hétero-militar brasileira". P recorremos aos pressupostos analíticos da História Cultural. Em termos genéricos, pode-se dizer que essa perspectiva teórico-metodológica, segundo Pesavento (2013), tem como proposta reorientar três noçóes basilares nos estudos historiográficos, a saber: representaçāo, imaginário e narrativa, de modo que a História passa a ser relida como uma narrativa interpretativa construída sobre o acontecido e năo como uma verdade inquestionável extraída dos documentos. Portanto, entre o que aconteceu um dia, num tempo e espaço nâo mais alcançáveis, e a narrativa, há uma mediaçâo irreversível:

\footnotetext{
A figura do narrador - no caso, o historiador, que narra o acontecido - é a de alguém que mediatiza, que realiza uma seleçâo dos dados disponíveis, que tece relaçóes entre eles, que os dispóe em uma sequência dada e dá inteligibilidade ao texto. Tais atividades envolvem a montagem de uma intriga, a urdidura de um enredo, a decifraçâo de um enigma. O narrador é aquele que se vale da retórica, que escolhe as palavras e constrói os argumentos, que escolhe a linguagem e o tratamento dado ao texto, que fornece uma explicaçăo e busca convencer (PESAVENTO, 2013, p. 28).
}

O historiador é, assim, aquele que se vale dos indícios para re(a)presentar sua mediaçăo entre o que aconteceu um dia, num tempo e espaço năo mais alcançáveis, e a narrativa. Maffesoli (1998) propóe a substituiçáo do termo representaçâo por apresentaçấo. Para o autor, representar conserva o ideal moderno de acessar o mundo em sua verdade universal e incontornável. Por outro lado, apresentar o mundo sinaliza o re-conhecimento do dinamismo, complexidade e vitalidade desse mundo. Maffesoli năo nega, com isso, a importância da representaçăo na construçăo da realidade, mas acredita que é preciso re-conhecer que a representaçăo "nasce-com" o mundo que supostamente busca explicar. É o que Roger Chartier (2011) chama de opacidade enunciativa, ou seja, que toda representaçăo se apresenta re(a)presentando algo. Preferimos a utilizaçăo do termo re(a)presentaçăo por assinalar graficamente ambas as dimensôes dos processos representacionais.

Nesse sentido, aproximamo-nos do paradigma indiciário formulado por Carlo Ginzburg (1990), segundo o qual a narrativa pode apresentar alguns indícios do "haver

3 A reflexăo e análise aqui desenvolvidas fazem parte do projeto de pesquisa de mestrado desenvolvido por Ricardo Afonso-Rocha sob orientação de André Luís Mitidieri intitulado "Quem tem cu, tem medo: literatura, deimopolítica, homossacralidade e ditadura no Lampiâo da Esquina", fomentado pela Fundaçăo de amparo à pesquisa no Estado da Bahia (FAPESB). 
sido" das coisas. Diante disso, Ginzburg (1990) entende que ficçáo expressa a saída entre a verdade e a mentira, de modo que fictio remete a construçâo interpretativa a partir do real, isto é, com base no que já existe. Se a realidade năo é transparente, devemos interpretá-la. O "acontecimento", entăo, năo passa de construçăo interpretativa fundamentada em uma "densa rede de interpretaçōes" baseada em indícios do "ter acontecido".

Em sentido similar, mas năo idêntico, Ricoeur (2010) afirma que o vestígio significa sem fazer aparecer. Imbuído dos pressupostos fenomenológicos, o autor destaca que o vestígio marca sempre a passagem, nunca a presença. É o registro do "tendo-sido-aí" temporal e espacialmente delimitado a partir da relaçáo entre o "tempo vulgar" e o "tempo estrelar". Em nossa leitura pretendemos, assim, apreender os indícios que permitem evidenciar uma dimensăo cis-hétero-ditatorial no regime militar brasileiro, tomando como local inicial de análise, como também local de partida, a literatura publicada no jornal Lampiāo da Esquina.

Evitamos a utilizaçăo do termo literatura marginal por ser muito específico da poesia da década de 1970 (CABANAS, 2005) e por considerar que, nessa época, a literatura homoerótica năo estava à margem, local ainda possível de ser visto, mas se encontrava no subterrâneo, longe, assim, do espectro visível da elite intelectual brasileira. 0 valor transgressivo dessa literatura deve ser analisado tendo em questăo o contexto ditatorial de uma época na qual "[...] quem ousava proclamar 'é maravilhoso ser fresco, trans-viado' estava sujeito náo apenas ao estigma e opróbrio popular, mas corria até o risco de ser processado pela Polícia Federal - como ocorreu com os fundadores do citado jornal gay tupiniquim, O Lampiâo" (MOTT, 2002). Por isso, propomos o termo "Literatura ctônica": lançada ao subterrâneo, a literatura homoerótica faz do gueto sua potência dionisíaca para resistir. Ctônico significa, na mitologia grega, "relativo à terra" e remete, conforme Maffesoli (2012), aos deuses e espíritos do mundo subterrâneo ou telúrico, em oposiçấo aos deuses olímpicos (também denominadas uranianos - relativo ao céu), símbolos da perfeiçăo, certeza e beleza.

A expressăo literatura ctônica ou subterrânea alude, assim, às notaçôes culturais embebecidas no cotidiano, de modo a problematizar as relaçōes de poder intrínsecas a re(a)presentaçáo de algumas práticas em detrimento de outras. O foco da narrativa sai, portanto, dos grandes acontecimentos e temas "universais" para os sujeitos e práticas do cotidiano. Ao realizar esse movimento, a literatura ctônica pode permitir a ascensăo do subterrâneo e, no mais das vezes, possibilitar outra re(a)presentaçâo sobre o passado, escapando, assim, às representaçōes hegemônicas, figuradas em homens, heterossexuais, brancos, cristăos, burgueses, urbanos.

É nesse sentido que a literatura do Lampiāo da Esquina comparece para resistir a um real náo problemático. Mergulhado nesse real, construído a partir da percepçâo do presente, o leitor pode (re)conhecer uma dimensăo cis-hétero-militar na ditadura brasileira, de modo que a re(a)presentaçăo sobre o passado possa, entăo, vir a ser problematizada e questionada. Ctônica é a literatura que resiste à unicidade do real. Nesse sentido, se aproxima da embriaguez de Dionísio (NIETZSCHE, 2007), divindade que melhor congrega, na mitologia grega, as características telúricas, entidade sempre a transitar entre o sagrado e o profano. 
Entusiasmados, assistimos, no Lampiâo, ao desenvolvimento de uma literatura ctônica, tribal, cuja funçáo ético-estética foi a de diluir o Uno em uma interaçăo orgástica e orgiasticamente coletiva: "O que o Ocidente reprime em sua visăo da natureza é o ctônico, que significa 'da terra' - mas das entranhas da terra, năo da superfície. O dionisíaco năo é nenhum piquenique. Săo as realidades ctônicas de que foge Apolo, o triturar cego da força subterrânea, o longo e lento sugar, a treva e a lama" (PAGLIA, 1990, p. 17).

A partir dos indícios re(a)presentados no Lampiâo da Esquina, em cotejo com uma rede densa de informaçóes sobre referido período, entendemos que a ditadura cis-hétero-militar (1964-1988), instalada no Estado brasileiro a partir do golpe de 1964, trouxe contornos expressivos para a regulaçăo das subjetividades, assumindo, ainda que por vezes de modo oblíquo, políticas estatais de produçâo da sexualidade normal. Ainda que năo se possa afirmar que houve uma política unitária e homogênea de extermínio direcionada aos sujeitos e as práticas desviantes em termos morais, especificamente no que tange à sexualidade, parece-nos justificado assegurar que houve, na ditadura militar brasileira, políticas sexuais (no plural), muitas vezes até contraditórias, coordenadas pelos diversos órgăos estatais.

Renan Quinalha (2017) reflete sobre uma possível dimensâo "hétero-militar" da ditadura brasileira. Porém, os dispositivos de produçâo atuantes sobre os sujeitos sexualmente dissidentes, nesse regime, produziam năo apenas um corpo heterossexual, mas também um corpo cis, sendo, portanto, notório o acirramento da perseguiçaáo e produçâo direcionada às pessoas transexuais, travestis e transgêneros. Embora Quinalha tenha notado a produçâo do corpo em torno da cisgeneridade, o termo "hétero-militar" parece omitir ou ocultar a dimensăo cisnormativa da ditadura brasileira. Sendo assim, a reescritura do termo em ditadura "cis-hétero-militar", proposta por Afonso-Rocha (2018), tem por objetivo destacar a produçấo do corpo e das sexualidades em torno da cisgeneridade:

Em relaçăo ao que chamei de ditadura cis-hétero-militar [...] identifiquei, no regime militar, o surgimento, enquanto técnica de governo, de uma política oficial de intensificaçăo da cis-heterossexualidade em detrimento das demais expressôes sexuais, ainda que avocada de forma enviesada e descentralizada. ( p. 9).

A ditadura reestruturou, assim, o complexo sistema de controle moral implementado, ou pelo menos intensificado, a partir da ditadura varguista com seus anseios nazifascista (COWAN, 2015; GREEN, 2000). Sendo por certo que existiram políticas deliberadas de controle das sexualidades e das práticas dissidentes, bem como de produçâo do cis-hétero-corpo reprodutivo. A afirmaçăo da existência de uma dimensâo sexual do regime se fundamenta nos relatórios da Comissăo Nacional da Verdade, Comissâo Estadual da Verdade do Estado de Sâo Paulo e do Rio de Janeiro, bem como as pesquisas desenvolvidas por James Green (2000), Benjamin Cowan (2015), Joâo Trevisan (2000), Renan Quinalha (2015; 2017), Rita Colaço (2012), Marisa Fernandes (2015), Luis Morando (2015), dentre outros.

Năo negamos que, antes do regime autoritário, houvesse a produçăo de sexualidades heréticas, conforme conceitografia de Foucault (2017), em torno do cis-hétero-corpo, ou que, uma vez findo o período cinéreo, essa produçăo tivesse sido superada e, com ela, todo o aparato repressivo/produtivo desaparecesse. Embora o preconceito contra as sexualidades dissidentes nâo surgisse na ditadura militar, nem desaparecesse com 
o seu fim, a valorizaçăo da cis-heterossexualidade nesse período foi assumida como política estatal heterogênea, derivando de múltiplos polos de gerenciamento e pressâo popular, como veremos. A relevância teórica desta pesquisa reside, pois, na necessidade epistemológica e política - já que pautada num princípio de reconhecimento atinente ao vetor da justiça de transiçấo - de se compreender a sensibilidade estética, presente no jornal Lampiâo da Esquina, como expressáo da resistência, tal como definida por Norberto Bobbio (2004) enquanto ato ou comportamento de ruptura contra a ordem constituída que, pelo estrito fato de produzir-se, pōe o sistema em crise.

É importante, ainda, refletir sobre como o periódico contestava a realidade unidimensional (im)posta pelo regime, a partir de sua coluna literária. O jornal foi objeto de estudo por diversos autores, havendo um número considerável de trabalhos acadêmicos publicados, entre artigos, dissertaçóes e teses. Porém, após várias buscas nas plataformas online, nâo encontramos nenhum trabalho analisando especificamente a coluna literária do jornal. Os diversos trabalhos publicados sobre o Lampiâo quase que exclusivamente desconsideram a referida seçâo ou lhe atribuem peso menor, focando prioritariamente nas matérias jornalísticas, artigos de opiniâo, editorial, entrevistas.

A pertinência prática exterioriza-se na inevitabilidade de, no contexto atual de risco concreto de ruptura democrática ${ }^{4}$, instrumentalizar, por vários meios, dentre eles, o fazer científico, a concretizaçăo do direito à memória, à verdade e à justiça, diletos à consolidaçáo do ideal comunitário. Justificamos, ademais, que a temática do presente trabalho é pouco prestigiada nas pesquisas acadêmicas e nas políticas públicas de verdade, memória e justiça, em relaçăo aos crimes cometidos durante o golpe que depôs o presidente Goulart e instaurou um regime autoritário.

\section{"É PRECISO DIZER NÃO AO GUETO E, EM CONSEQUÊNCIA, SAIR DELE"5}

O projeto Lampiāo surgiu a partir da entrevista com Winston Leyland - editor do Gay Sunshine, tabloide americano dirigido ao público guei ${ }^{6}$-, feita por Joăo Antônio Mascarenhas, entăo colunista do Pasquim. Após a entrevista, o grupo se reuniu na casa do escritor e artista plástico Darcy Penteado, em São Paulo, encontro que marcou o início daquele jornal. Os onze criadores passaram a integrar, assim, o Conselho Editorial, apresentado no número experimental do Lampiâo, sendo eles: Adăo Costa; Aguinaldo Silva; Antônio Chrysóstomo; Clóvis Marques; Darcy Penteado; Francisco; Gasparino Damata; Jean Claude Bernardet; Joâo Antônio Mascarenhas; Joâo Silvério Trevisan; Peter Fry. ${ }^{7}$

4 Uma das primeiras medidas tomadas pelo governo brasileiro em 2019 foi retirar a populaçăo LGBT+ das diretrizes de Direitos Humanos, ato comemorado por setores evangélicos conservadores: "Bolsonaro assina MP que acaba com o tratamento vip dado aos lgbts. E SO O COMEÇO! SEGURA QUE VEM MAIS!" (sic) (MALAFAIA, 2019). Isso nos leva a questionar: o que resta da cis-hétero-ditadura brasileira?

5 Excerto extraído do editorial de inauguraçâo do Lampiâo da Esquina, assinado pelo Conselho Editorial.

6 Os editores do Lampiâo mudaram a grafia da palavra gay para "guei", numa forma de abrasileirar esse termo que começava a ser usado como sinônimo de homossexualidade masculina e feminina. Conforme Jorge Rodrigues (2015), havia uma direçáo editorial implícita no jornal para recusar a cultura americana, "[...] o projeto do Lampiăo era seguir contra a corrente made in USA" (p. 104).

7 No documentário Lampiâo da Esquina, Lívia Perez (2016) retrata a trajetória do jornal que circulou de 1978 a 1981. 
Esse veículo, com ediçăo mensal e tiragem entre 10 e 20 mil exemplares, conforme relatos dos editores do periódico, significava, de imediato, um confronto direto com o regime cis-hétero-militar. O jornal tensionou, assim, o regime autoritário que visualizava a ameaça comunista e as subversóes sexuais como os maiores perigos enfrentados pela naçăo brasileira. Já que supostamente constituiriam óbices considerados suficientes para impedir o crescimento e o fortalecimento do Brasil, era necessário direcionar o aparato estatal contra essas práticas.

Embora o Lampiāo da Esquina surgisse durante o período de abertura política de 1970 - no contexto da imprensa alternativa, durante os anos de suavizaçâo da censura política promovida pela ditadura -, a censura moral, direcionada às práticas homossexuais e aos sujeitos que as realizavam, seguia firme. Isso porque, conforme relata Renan Honório Quinalha (2017), os setores sociais que apoiavam o regime náo estavam satisfeitos com a promessa de redemocratizaçăo e buscavam, assim, preservar a hegemonia da moralidade conservadora. Nessa direçăo, Benjamin Cowan (2015) afirma que, após a queda da resistência armada, dizimada em 1970, as forças de segurança viraram-se quase que exclusivamente contra os subversivos morais, como forma de conduzir o desejo das massas na manutençăo do regime. Intensificou-se a figura do inimigo moral cooptado pelo Movimento Internacional Comunista para promover o desmoronamento da naçăo por meio da desarticulaçăo dos seus pilares: a moral cristâ e a família tradicional burguesa. Nessa época, a Polícia Federal informou que as organizaçôes comunistas recrutaram homossexuais e prostitutas para suas fileiras de luta (COWAN, 2015), o que justificou, em nossa leitura, a intensidade na produçấo da cis-hétero-norma durante a abertura política.

Entendemos que a literatura homoerótica publicada no Lampiăo constituiu um espaço de resistência, "heterotópico", diria Foucault (2013), por ser um desses locais reais, efetivos de contestação mítica, simbólica e imaginária do tempo e espaço em que vivemos:

[...] lugares que săo desenhados na constituiçăo mesma da sociedade, e que săo algo como counter-sites/ contra-sites, espécies de utopias efetivamente realizadas nas quais os lugares reais, todos os outros lugares reais que se pode encontrar no interior da cultura, sáo simultaneamente representados, contestados e invertidos; espécies de lugares que estăo fora de todos os lugares, mesmo quando eles sejam efetivamente localizáveis (FOUCAULT, 2013, p. 4).

A literatura lampiônica também se constituiu como espaço de "homossocialidade", conforme conceitografia de Michel Maffesoli (2012). Isto é, os vínculos de socialidade, e as formas de estar-junto ali anunciadas, significaram experiências transindividuais homoeróticas, contrárias aos valores e à moral impostos pelo regime cis-hétero-militar que se deu com apoio de setores expressivos da sociedade:

Faz-se necessário, mais uma vez, encontrar a palavra adequada para designar a homossocialidade náo-ativa do vínculo social em gestaçăo: vitalidade ora lúdica ora anômica. Para retomar uma expressáo de Guy Debord, essa 'prodigiosa inatividade', deveras ameaçadora à ordem estabelecida, concernia senăo a alguns grupos vanguardistas, boêmios, marginais ou excluídos voluntariamente. Năo é mais o caso. Toda ocasiăo parece propícia para viver em grupo essa perda de si no 
outro, esse orgíaco do qual a ambiguidade sexual de Dionísio e as bacanais por ele inspiradas constituem os exemplos acabados. (MAFFESOLI, 2012, p. 4).

A vivência homoerótica, re(a)presentada na literatura lampiônica, manifestou-se, nesse viés, como exercício da resistência, já que fundada em um pensamento amoroso e homoerótico da vida em sua integralidade, contrário à atitude normativa (MAFFESOLI, 1998) que se justificava na hiper-realidade, isto é, no imaginário de uma realidade transparente, pretendida e sustentada pela ditadura. Passemos, entăo, à análise dos textos publicados na coluna "Literatura" do Lampiâo. Apresentamos, por amostragem, recortes das ediçóes publicadas em 1978, ano de surgimento do jornal, entendendo que, nesse período, melhor concretizou seu objetivo de contestar a produçáo estereotipada do homossexual, bem como de questionar a imaginária unidade do real em torno da cis-hétero-norma.

A ediçăo número zero trouxe, na coluna "Literatura", três poemas de jovens poetas até entâo desconhecidos pelo grande público: Leila Míccolis, Franklin Jorge e Paulo Augusto. Os poemas têm como temática o amor e os afetos ctônicos, mas também a sexualidade e o ato sexual. Sáo poemas sujos, nâo eufeminizados, poeticamente vaginais, anais e fálicos - por isso, transgressivos.

O poema de Paulo Augusto - "Na pensăo a flor de Minas" - é erótico, direto, político e subversivo; conserva certa sutileza irônica ao questionar o regime de cis-heterossexualidade. $\mathrm{O}$ eu-lírico ousa assumir seu desejo por outro homem: "O rapaz do quarto 14 é rebento 24 anos,/ da tradicional família mineira/Olhou nos meus olhos/ um dia/ seu pecado feito carne/ e viu meus cílios baterem/Ele estremece,/ foge o olhar - mas fala. Disse-me que tem muito medo" (AUGUSTO, 1978, p. 10). O poema de Augusto re(a) presenta indícios de uma situaçâo peculiar ocorrida em Minas Gerais. Antes mesmo da deflagraçăo do golpe militar de 1964, em Belo Horizonte, intensificava-se a perseguiçăo aos homossexuais e às travestis.

Luiz Morando (2015) mostra-nos o notório acirramento da produçâo negativa dos sujeitos homoeroticamente inclinados na cidade, pelo menos desde 1961, com a ediçâo de leis e portarias utilizadas para embasar essa repressăo ${ }^{8}$. O termo "tradicional família mineira" tornou-se um signo comum para se referir ao conservadorismo do regime e às políticas sexuais ostensivas contra as minorias sexuais. Diante da expectativa do medo e da ideia de pecado, o eu-lírico assume os prazeres mundanos, transcendendo os valores morais centralizados na família cristă: "estou sempre,/ esperando que na ida para o banheiro/ a cupidez mineira/ da família tradicional/ permita o medo dele vir/pelo meu quarto/misturar na noite fria de junho/ nossas humanidades/ no pecado amplo,/ fofo,/ que deitado estou para isso..." (AUGUSTO, 1978, p.10).

“O poema para teus seios", de Leila Míccolis, é uma profanaçăo poética: "Cerro olhos pra năo ver,/ e máos pra năo apalpar,/ e bocas pra năo chupar/ teus seios" (p.10). Segundo Giorgio Agamben (2005), profanar possui um sentido contra-dispositivo, que é o de retirar algo do uso restrito dos deuses e devolvê-lo ao uso comum do povo.

8 Nesse caso, falamos em repressâo entendendo que a produçăo dos corpos homossexuais se deu, no limite, pela repressăo, tendo-se em conta que toda repressăo já é um meio de produzir desde a sua base (dis) positiva. Em outros termos, tanto o enunciado negativo "nâo pode x" tem valor residualmente positivo, quanto o positivo "pode y" vale residualmente como negativo. 
A literatura foi por muito tempo o lugar do sublime e da perfeiçăo, con-sagrado aos deuses. Inacessível ao uso comum, seu caráter sagrado castra os desejos e silencia os prazeres, apagando o sexo, amputando o corpo. Profanada, a literatura resiste e assume, de uma forma ou de outra, sua funçăo tribal de notaçăo democrática; lançada ao subterrâneo, faz do submundo a sua potência dionisíaca para resistir. O eu-lírico profana esse lugar estabelecido, para restituí-lo ao livre gozo dos desejos humanos: “Desejo beber teu leite,/ azeite de oliva branca,/ e provar com minha língua/ o macio do teu peito./ E se em inútil trabalho/ te afasta a blusa de mim,/ eu, por inúmeros meios,/ cerro olhos para ver/ e bocas para chupar/ teus seios" (MÍCCOLIS, 1978, p.10).

Outro poema, "Antropofagia", de Franklin Jorge, é um epinício ao prazer, personificado como realizaçăo espontânea da autonomia e que provém das nossas próprias necessidades: "Conduzo-te faminto/ até a velha cama,/ que é grande e redonda/ como uma mesa de banquete." (JORGE, 1978, p.10). Pelo semântico, transfigura-se o desejo de comer pela metáfora: o adjetivo faminto é deslocado da mesa para a cama. O corpo é deliciado como banquete. A literatura homoerótica só poderia ser antropofágica - num eterno ritual de comer homens - da cama grande para a glande. A mesa de banquete é signo da cama do "boquete". "Antropofagia" nos ensina a buscar o prazer de viver o gozo sem reprimi-lo, afinal, nossos corpos săo heterotopias antropofágicas: "Insalubres, nossas salivas/ se confundem./ Rolam nossos corpus suados/ sobre as tenras cobertas./ Bates persistente/ contra o meu umbigo/ com teu sexo - peixe cego. Arrancando-te os pelos das axilas,/ de pura agonia gozo" (JORGE, 1978, p.10).

Ainda nessa ediçâo, foi publicado o conto "Aniversário", de Moacir de Moura. A narrativa tem como moldura a comemoraçăo do aniversário de um militar ("eu sentia o tecido áspero de sua farda contra minhas pernas") com seu amante masculino. A figura do militar guei vivenciando seus desejos homossexuais é alegórica pois, além de questionar a castraçâo produzida pelo regime cis-hétero-militar, aponta para a desmitificaçâo da masculinidade militar; como também traz elementos indicativos da angústia vivida pelas personagens: "[...] eu senti o grande dia, e ele continuava sorrindo e seu sorriso, como o meu, era triste, e o ar do campo era leve" (MOURA, 1978, p.16). A narrativa tem seu clímax quando da descoberta pela família do militar da sua inclinaçăo homossexual: "a mulher, e a criança chorando e ele năo ligava, e ele gritava, a criança gritava e ela continuava em silêncio, e a criança continuava gritando e ela năo ligava, e eu olhei para ele, e ele havia esquecido de mim" (p.16). Contrastando com essa angústia, há, contudo, um ethos afetivo sentido em conjunto pelos amantes, intensificado pelo prazer do estar-junto, ainda que em circunstancias adversas: "ele foi para trás de uma árvore, e gritamos nossos nomes alto, e o eco repetiu nossos nomes, e corremos" (MOURA, 1978, p.16). Alusivamente, as personagens indicam que a vida deve ser vivida de maneira paroxista e emblemática aqui e agora, isto é, sinalizam que a vida merece ser vivida "apesar de". O desfecho da narrativa dá sinais da solidáo imposta aos homossexuais que, impedidos de viverem a completude de seus desejos e prazeres, săo lançados numa vida antropófoba: "pediu novamente que eu me fosse, e năo cumpriu sua promessa e deixou-me para sempre agonizante como mosca nadando em óleo" (MOURA, 1978, p.16).

Em maio de 1978, chegava às mâos dos leitores a ediçâo nº 1 do Lampiâo da Esquina cujo destaque foi o ensaio/entrevista "Confissōes de um Carmelita Descalço". 
O entrevistado, o padre espanhol Antônio Roig, da Ordem dos Carmelitas Descalços, lançara, em 1977, o livro "Todos los parques no son un paraíso", em que assumia sua homoeroticidade e reivindicava o direito de viver de acordo com a própria sexualidade, inclusive enquanto padre. $\mathrm{O}$ ensaio problematizou a posiçăo da Igreja frente à homossexualidade: "ela [a entrevista] vale como um documento sobre a posiçăo da Igreja em relaçăo aos homossexuais" (LAMPIÂO, 1978, n. 1, p.7).

A coluna literária trouxe, na mesma ediçâo, um capítulo do livro de Antônio Roig, que havia resultado em sua suspensâo: "Nem todos os parques sâo um paraíso". A estória se passa em Londres, onde o autor morou durante três anos e experimentou uma série de vivências importantes em torno de sua homossexualidade. A narrativa autobiográfica descreve a vivência homossexual do autor-personagem em um parque inglês, provavelmente na década de 1960. Embora os países integrantes do Reino Unido já fossem democráticos, nesse período, manter relaçôes homossexuais era considerado crime na Inglaterra e no País de Gales até 1967; na Escócia, até 1980; na Irlanda do Norte, até 1982. O texto expóe que, mesmo sob o manto da democracia inglesa, a vontade soberana produzia, agora como tática de exceçấo, e nâo mais como estado de excepcionalidade, o homossexual como homo sacer (AGAMBEN, 2007). No interior de uma democracia consolidada, os desejos homossexuais eram criminalizados, o sujeito homossexual tornava-se marginalizado e destituído de sua condiçăo de cidadăo, lançado a viver uma vida sem importância, sem proteçâo jurídico-política:

[...] o homo sacer apresentaria a figura originaria da vida presa no bando soberano e conservaria a memória de exclusăo originaria através da qual se constituiu a dimensâo política. $O$ espaço político da soberania ter-se-ia constituído, portanto, através de uma dupla exceçăo, como uma excrescência do profano no religioso e do religioso no profano, que configura uma zona de indiferença entre sacrifício e homicídio. Soberana é a esfera na qual se pode matar sem cometer homicídio e sem celebrar um sacrifício, e sacra, isto é, matável e insacrificável, é a vida que foi capturada nesta esfera (grifos do autor) (AGAMBEN, 2007, p. 91).

O homo sacer ou homem sagrado era uma figura do direito romano arcaico utilizada para rotular os indivíduos que haviam cometido crimes, normalmente contra as divindades. E que por isso, eram excluídos da vida social e tinham seus direitos civis eliminados, sendo, assim, retirados da vida comum. Ao ser legalmente declarada homo sacer, uma pessoa era excluída do direito e, consequentemente, da vida política da cidade. O proclamado "sagrado" năo podia ser legalmente morto - isto é sacrificado - embora pudesse ser morto por qualquer um com a garantia de que o responsável năo seria punido. Passava a viver uma vida nua, sem importância. Como sua vida năo tinha importância, quem o matasse năo teria supostamente cometido crime. $\mathrm{O}$ assim declarado "sagrado" era lançado em uma zona de indeterminaçăo político-jurídica, isto é, sobre ele nâo mais pairava a proteçâo do Estado de direito, sua vida estava nua, sem cobertura protetiva por parte do Estado. Assim como Pôncio Pilatos, o soberano lava suas mâos para se purificar do sangue reiteradamente derramado.

No texto em análise, essa condiçâo de homo sacer é revelada quando "O homem de idade mediana e eu nos juntamos. Havíamos notado uma mútua atraçáo. Com precauçóes, começamos a nos beijar e logo a tocar um no outro" (ROIG, 1978, p.16). Até 
que apareceu um homem mais jovem e se identificou como policial: "Terá que assumir sua responsabilidade por atos indecentes" (ROIG, 1978, p.16). O policial passou a agredi-lo com socos e pontapés. Por certo, a lei inglesa nâo autorizava esse tipo de agressấo, mas como já discorrido, ao declarar um sujeito como homo sacer, a vontade soberana o transforma em vida à mercê; matá-lo năo é mais um crime, visto que já năo goza dos atributos que o qualificariam como ser humano. Quando a vontade soberana já năo mais pode declarar explicitamente um indivíduo como homo sacer, incentiva a produçâo dessa categoria por meio de táticas de exceçâo: criminalizando as práticas homossexuais, desqualifica os sujeitos que săo agenciados por elas.

O policial agride porque sabe que a vontade soberana sustenta uma năo-puniçáo. O Estado faz vista grossa, quando náo incentiva diretamente esse tipo de violência. A partir dessa re(a)presentaçăo da ditadura nas páginas lampiônicas, é possível afirmar que há indícios da existência de uma dimensăo específica da sacralidade, a qual funcionou durante todo o regime cis-hétero-militar e que ainda persiste numa tentativa de nunca acabar: a homossacralidade.

O Lampiâo trazia um exemplo, a partir da literatura autobiográfica, de como em uma democracia consolidada, a exemplo da inglesa, a homossexualidade era, ainda, produzida em torno da normalidade cis-heterossexual, que relegava a homossexualidade às sombras e, consequentemente, aos temíveis efeitos da condiçâo de sacer:

Com outro golpe me jogou no chăo. O lábio inferior começou a sangrar. Desta vez năo pude levantar. Tudo girava ao meu redor. Ele inclinou-se sobre mim e apropriou do meu porta-moedas. Quando afinal me levantou, me ameaçou. - 'Que eu náo volte a vê-lo por aqui, porque do contrário o matarei' (ROIG, 1978, p.16).

Entendemos que, na ditadura cis-hétero-militar brasileira, em se tratando de existências bixas, náo podemos falar de vidas matáveis, mas corriqueira e reiteradamente violentadas e mortas. A potência se transformou em atos, numa política de Estado assumida pelo regime ditatorial, embora de forma heterogênea e oblíqua, por meio da produçấo do sexualmente dissidente como vida sem atributos específicos de humanidade: "Nesse caso, a soberania é a capacidade de definir quem importa e quem năo importa, quem é 'descartável' e quem nâo é." (MBEMBE, 2018, p.135). Para acentuar essa singularidade brasileira, elaboramos o termo homossacralidade, no sentido de que o risco potencial a que todos estaríamos submetidos, conforme Agamben (2007), em sermos declarados homo sacer, foi diariamente concretizado no regime cis-hétero- militar brasileiro quando direcionados às vidas bixas. $O$ estilo e a ética de vidas bixas proclamaram-se sagrados; sujeitos dissidentes sexualmente, declarados descartáveis. O Estado brasileiro particularizou a universalidade da figura do homo sacer, transfigurando-a no fenômeno homossacralidade.

A noçấo de homossacralidade visa deslocar a ideia eurocêntrica e universalista do homo sacer - limitada ao horizonte referencial: europeu, branco, hétero, homem. Como destaca Pedro Gomes Pereira (2015, p. 423): “Na obra de Agamben, contudo, o gênero dos atores năo é questionado ou pensado como parte da vida - o homo sacer năo é considerado em sua dimensăo de gênero e sexualidade". Pretendemos, com essa noçấo, questionar a sexualidade daquele, refletindo sobre o peso da dissidência sexual na declaraçăo e fundamento da sacralizaçăo da vida. 
A propositura dessa dimensáo real do homo sacer, a partir da experiência ditatorial brasileira, confronta e questiona a condiçáo potencial masculina, ocidental e heterossexual daquele. A quem se direcionavam as políticas estatais de extermínio e violência? Quais subjetividades tiveram o rótulo de perigosas e quais receberam a proteçăo e a compaixăo estatal? Sob a universalidade do homem sagrado, as vidas que importam se potencializaram, enquanto as diferenças foram homogeneizadas, violentadas e exterminadas. O homo sacer teve, na ditadura brasileira, uma raça, uma identidade e uma orientaçăo sexual, assim como, em última instancia, uma classe social, bem definidas. Năo se tratava, ainda que queira Agamben, de um sujeito fixo, universal, sem espessuras, afinal "nem todas as vidas săo nuas. Algumas nascem para viver, outras se tornam vidas matáveis pelo Estado" (BENTO, 2018, p. 4).

Evidentemente, a ficçăo universalista do homo sacer năo considera a existência de vidas mais valiosas do que outras, deixa de problematizar, com isso, as vidas que importam, vidas que năo correm o risco de serem expostas, mesmo se em potência. A generalizaçăo agambeniana apaga e silencia as marcas dos processos que separam vidas vivíveis das matáveis. O lugar do qual fala Agamben aparece, embora à revelia: homem, hétero, ocidental, que carece de um olhar mais atento para os sujeitos concretos. Uma análise do regime militar pelas lentes do filósofo italiano dificulta, senăo impede, a problematizaçâo das diversas vulnerabilidades.

Em 25 de junho de 1978, o Lampiâo publicava sua ediçâo n 2 . A coluna literária trazia "Do outro lado da porta", um texto de M. Rocha que narra a rotina de um casal guei. Como a luta diária contra o estigma e o estado de vergonha impostos pela sociedade, a narrativa apresenta alguns dos inconvenientes enfrentados por gueis assumidos: "Nunca pude entender direito as suas fugas repentinas no meio das festas. Procurava pensar que era pelo fato de uma claustrofobia social, mas quando regressava solitário para casa, concluía ser pelo estado de dúvida que o amargurava" (ROCHA, 1978, p.8). O estado de dúvida, de vergonha, a fragilidade emocional, o estigma, tudo serve para fortificar o lugar social construído para sujeitos que ousam amar e, mais ainda, para os que ousam apenas gozar fora dos padrôes produzidos. Na ausência de referências e de apoio moral, muitos homossexuais năo suportam esse locus social de desprezo e de insignificância no qual săo atirados: "Na primavera passada, sem dizer uma palavra, ele retirou a mala de dentro do armário e começou a jogar as peças de roupas com uma fúria incontrolável. [...] Corri até a janela ainda a tempo de vê-lo tomar o ônibus azul e acomodar-se na última poltrona" (ROCHA, 1978, p.8). Aqui mais uma vez, a homossacralidade se faz presente: o locus social de desprezo expressa, assim, potencialmente os efeitos da declaraçăo de homo sacer. Potencializado por essa condiçấo, o abandono do companheiro pode, dessa forma, re(a)presentar uma fuga de si, uma tentativa de viver livre do estigma e da vergonha, e é produzida nos contornos do regime cis-heteronormativo. O abandono náo é do outro, apenas, mas da própria luta por si.

Lembremo-nos que o poder produz a realidade, antes de reprimi-la ou adoçá-la, conforme Foucault (2017). A esfera produtiva das relaçōes de poder é mais sutil, engenhosa. O poder é uma açăo sobre açôes que normaliza, incita, motiva, descompromete, robotiza, disciplina, suscita, cria desejos, afetos, emoçōes. A imagem do homem cis-heterossexual é produzida como normal, de maneira que toda e qualquer tonalidade que nâo se espelhe nessa produçâo semiológica da realidade é atirada ao signo da 
anormalidade. A produçăo da sexualidade, dos desejos, dos sentimentos, dos afetos, e até das nossas açôes năo escapam à cis-hétero-norma, reforçamos, matrimonial e cristâ. Assim, para o homossexual cujos desejos e prazeres nâo escapam à política unidimensional, a vida sempre será vida mutilada, é sempre vida à mercê, fora do prazer, de castraçăo dos desejos, o lugar do vazio. Amar ou gozar para além dos prazeres oficiais torna-se o maior dos desafios, uma resistência democrática que causa furor e engasgo ao ser exercida.

O número 3 do jornal publicou o conto "O maricas", do escritor argentino Abelardo Castillo que, narrado pelo protagonista, na primeira pessoa do plural e do singular, dá conta de uma experiência compartilhada entre ele e César, amigo de infância. O jogo alusivo a Jorge Luis Borges, a partir do momento em que o narrador-personagem repete o nome do autor, instaura-se também por intermédio da narração retrospectiva, como a simular um fato autobiográfico nos meandros da ficçáo literária. Na verdade, trata-se de uma confissâo da personagem central, claro que estilizada em sua narrativa breve: "Pois há coisas, palavras que a gente leva conosco como mordida, toda vida, mas uma noite sente que deve escrevê-la" (CASTILLO, 1978, p. 16). Conforme Foucault (2017), a confissăo foi colocada, pelo menos desde a Idade Média, como um dos rituais mais importantes dos quais se espera a produçáo de verdade:

O indivíduo, durante muito tempo, foi autenticado pela referência dos outros e pela manifestaçăo de seu vínculo com outrem (família, lealdade, proteçăo); posteriormente passou a ser autenticado pelo discurso de verdade que era capaz de (ou obrigado a) ter sobre si mesmo. A confissăo da verdade se inscreveu no cerne dos procedimentos de individualizaçăo pelo poder (FOUCAULT, 2017, p. 57).

A confissāo integra, assim, um dos procedimentos de exclusăo discursiva (FOUCAULT, 1998). Regida por nossa "vontade de verdade", o que está em jogo nesse mecanismo de exclusáo é o poder e o prazer: "O poder funciona como um mecanismo de apelaçăo, atrai, extrai essas estranhezas pelas quais se desvela. O prazer se difunde através do poder cerceador e este fixa o prazer que acaba de desvendar." (FOUCAULT, 2017, p. 44). O ato confessional de Aberlado pode muito bem ter como objetivo aparente desculpar-se por um erro cometido no passado e libertá-lo da vergonha que veio a sentir por isso. O narrador-personagem busca-o perdăo de César, por năo ter defendido o amigo quando era insultado, aos gritos de "marica" e por ter se acovardado: "E dava vontade de gritar que todos nós juntos náo valíamos a metade do que tu valias, mas naquele tempo a palavra era difícil e o riso fácil" (CASTILLO, 1978, p. 16). Ainda deseja ser perdoado por náo ter tido como expressar que "te quis de fato, inexplicável e obscuramente". A personagem central descreve o episódio resultante no afastamento entre os amigos, quando um dos meninos sugeriu que procurassem "[...] uma gorda que cobra cinco pesos, vamos e já aproveitamos para fazer o machăo debutar, o César" (CASTILLO, 1978, p. 16). Aberlado enganou César para que fosse à casa dessa mulher, sem saber que os garotos planejavam suas iniciaçôes sexuais. Assustado, esse foge e aquele, após sair do quarto da gorda, vai ao seu encontro: "A máo me queimava, mas era necessário bater, machucar, sujar-te para esquecer aquela coisa como um orgulho que me afogava" (CASTILLO, 1978, p. 16). Antes de que o amigo vá embora, o narrador-personagem grita: "maricas de merda". 
No entanto, a escrita pode, igualmente, funcionar como mecanismo de incitaçăo do prazer e poder: "Prazer em exercer um poder que questiona, fiscaliza, espreita, espia, investiga, apalpa, revela; e, por outro lado, prazer que se abrasa por ter que escapar a esse poder, fugir-lhe, enganá-lo ou travesti-lo. Poder que se deixa invadir pelo prazer que persegue e, diante dele, poder que se afirma no prazer de mostrar-se, de escandalizar ou de [confessar]" (FOUCAULT, 2017, p. 44). No texto ora analisado, após vários anos, Aberlado nâo consegue se libertar da vergonha, tais palavras o devoram, queimam-no. Por isso, ele precisa se confessar: "Aquela noite, ao sair do quarto da gorda, eu lhe pedi que, por favor, náo contasse aos outros. Porque aquela noite eu năo pude. Eu também năo pude" (CASTILLO, 1978, p. 16). Para năo ser taxado de "marica", a personagem renuncia a seus desejos e prazeres.

A cis-heteronormatividade faz com que muitos de nós repitamos os passos da personagem: tornando-nos violentos com tudo aquilo capaz de nos lembrar que somos nós os diferentes. A sexualidade do outro passa a ser, entăo, o calcanhar de Aquiles, afinal, aponta para nossa vulnerabilidade. Por nos sentirmos incapazes, no mais das vezes, de suportar o estigma, a vergonha (im)posta ou pressuposta aos sujeitos homoeroticamente inclinados, reforçamos o discurso da homogeneizaçăo, até mesmo, atirando pedras em quem "desejamos inexplicável e obscuramente". Isso para que năo restem dúvidas quanto a nossa (frágil) masculinidade.

A tensăo trágico-erótica existente entre Aberlado e César aparece nas lembranças da personagem, a qual implora para que esse escute sua narrativa expiatória, em outro engenho que lembra a ficçăo borgiana, como de resto, outras narrativas literárias da modernidade, ao constituir a personagem como leitora e ao tratá-la como externa ao texto: "Escuta, César. É preciso que leias isto. Porque há coisas que se levam como mordidas, avivadas pela vergonha a vida inteira, há coisas pelas quais a gente sozinho se cospe na cara diante do espelho. Mas de repente, um dia, tem de dizê-las, confessá-las a alguém. Me escuta" (p. 16). Mais do que confessar sua homossexualidade (ainda em tributo a cis-heterossexualidade), confessa seu acovardamento, suas castraçôes, suas limitaçôes, confessa-se um sujeito amputado. Nâo se pode desconsiderar que as relaçóes de poder produzem o tipo ideal de masculinidade, incitam desejos, sonhos, suscitam açôes, criam expectativas, prescrevendo o papel que deve ser percorrido pelos sujeitos identificados como homens pela sociedade. O medo é, assim, inscrito no ser-guei, de modo que passa a "significar" sua existência. A identidade de guei é condicionada à covardia, para náo se aceitar e (auto)reprimir-se. A censura é, com isso, produzida em nós, para nós e muitas vezes por nós.

Em outro episódio que demonstra autocensura, a ediçăo $n^{\circ} 4$ do Lampiăo, de agosto de 1978, publicou o texto "A dona boazuda", de Pedro Hilário, narrado por um operário, aparentemente da construçâo civil, que vive em uma cidade grande. Andando nas ruas da cidade, o rapaz vê uma mulher que desperta sua atençâo: "quando vi a tal boazuda parada ali naquela esquina me arrepiei que nem galo de briga e só faltei cair duro pra trás, no que ela atravessou a rua e fez um sinalzinho assim pra mim. Aí, que fiquei doído de vontade" (HILÁRIO, 1978, p.16). Procuraram um local escondido para ficarem à vontade, de "desfrute, no achego, no cheiro. Comecei a dar beijos na dona pra deixar ela tonta e, quando já tava bem crespa de arrepio, eu ... zás! ..., arranquei a calcinha. Levei a mâo. Nem vâo acreditar no que eu segurei." (HILÁRIO, 1978, p.16). 
O operário demonstra sua frustraçăo ao perceber que a tal boazuda era uma travesti ou mulher trans. Como era possível tê-lo "enganado" assim? Diante desse "ultraje", o narrador-personagem resolve agredi-la: "Pois a boazuda era um tremendo de um macho igual a mim, que nem vocês mesmo. Ah, Ora que?! Dei lhe uma surra, bati pra valer, pra ensinar o safado a tomar vergonha na cara" (HILÁRIO, 1978, p. 16). Bateu tanto que chegou a sentir remorso, teve pena daquela mulher indefesa que apenas chorava, sem reagir às agressōes. Além da agressâo física, revelam-se procedimentos de violência simbólica, através da utilizaçăo de pronomes masculinos para se referir à travesti, evitando chamá-la de mulher: "é um macho". Envergonhado pelo que tinha feito, o narrador-personagem reconhece seu erro:

Me arrependi de ver a tal de cabeça baixa, aleitando a pulseira de figa, sem coragem de me olhar na cara, na certa, com receio de que eu começasse a bater de novo. Fiquei achando que eu tinha sido mau com ela, porque ela tinha se agradado de mim e me beijou e me chamou de 'amorzinho' (HILÁRIO, 1978, p. 16).

Após narrar que pediu perdāo e tiveram, entăo, uma noite de sexo, o narrador-personagem desabafa, expondo novamente seus preconceitos: "Pra que tanto riso, heim? Năo văo me dizer que nunca frequentaram uma cabritinha, heim? Quando a gente tá a seco, qualquer cachaça serve, e a gente bem que gosta, Entăo, năo? E essa minha de ontem foi assim também" (HILÁRIO, 1978, p. 16). O operário demonstra viver um conflito intenso: sua agressáo marca o desejo obscuro que sentiu pela mulher; ele sabia que nâo houve engano, desejou-a ardentemente por ser quem era. Nessa cis-narrativa, apenas o ponto de vista do operário é apresentado. A mulher trans é objetificada pelo narrador-personagem, que nâo a reconhece como igual. Por isso, agrediu-a, por ter-lhe "provocado" malditos desejos. Visualizamos, nessa atitude, características transfóbicas, ridicularizando pessoas que năo se enquadram na cis-hétero-norma. Embora se arrependa de tê-la agredido, o narrador-personagem se refere a mulher trans com desdém: "a tal", "quem nunca frequentou uma cabritinha". E, sente a necessidade de se justificar pelo ocorrido: "qualquer cachaça serve", "Eu estava necessitado, ela apareceu, eu quis, ela quis, a gente fez".

O texto de Hilário denuncia a invisibilidade das pautas, reivindicaçôes, interesses dessa populaçấo: "Se é verdade que o Estado pode se apropriar das vidas, transformando-as em zoé (mera existência biológica), com as vidas trans, há singularidades. Năo se trata aqui de vidas sacrificáveis, mas de vidas reiteradamente sacrificadas. A potência anunciada transforma-se em política" (BENTO, 2017, p. 264). Inviabilizadas pelo movimento mainstream que teima em se autoproclamar "movimento gay", a populaçáo trans e travesti é duplamente vitimizada. Sob o signo "gay", escondem-se táticas pornográficas que buscam homogeneizar a diferença. "Somos todos uma família" expressa muito bem essa colonizaçăo do "subterrâneo". Elias e Scotson (2000) apontam que os estabelecidos temem perder sua hegemonia, a segurança da identidade fixa e do sujeito imutável. Por isso, tentam expurgar as diferenças. Porém, muitas vezes, os ditos estabelecidos sâo outsiders que conseguiram firmar bases sociais, ainda que inconsistentes e frouxas. O homem, guei, branco, urbano, burguês, entăo, ao se ver como estabelecido, teme perder a hegemonia (da diferença - é ele o único diferente, única vítima de preconceitos e discriminaçôes). Para conservar sua hegemonia, uniformiza 
as diferenças, negam-se os diversos graus de vulnerabilidade e se festeja a pluralidade do igual, a diversidade que aceita apenas o Um: "viva o orgulho gay!".

$\mathrm{Na}$ contracorrente da homogeneizaçâo assim estabelecida. a literatura lésbica apareceu na ediçấo ${ }^{\circ} 5$ do jornal. Cassandra Rios escolheu o texto "A hora do amor", integrante do livro A santa vaca, entâo inédito, publicado em 1978. Cassandra foi a escritora mais censurada pelo regime cis-hétero-militar, cf. Comissăo Nacional da Verdade. Năo apenas a temática lésbica assustava os censores, a literatura de Cassandra tinha algo a mais: era contra a castraçâo do gozo, a amputaçâo dos prazeres, a eliminaçâo dos desejos lésbico-femininos. Conforme Rick Santos, Cassandra re(a)presentou vidas e subjetividades gueis e lésbicas em sua literatura, propondo, com isso, "um desafio enorme à visăo dominante e monolítica que cristaliza homossexuais como objetos do seu olhar" (2003, p. 20). A sexualidade desnuda-se em suas palavras: sexo lésbico, sexo nu, sexo cru, sexo marginal, sexo sujo, sexo entre mulheres: "minhas mâos alisavam meu corpo e meus dedos burilavam os bicos dos meus seios para masturbar-me sequiosa e incapaz de impedir ou frear os impulsos de um desejo mais forte do que a razăo" (RIOS, 1978, p.16).

A literatura de Cassandra situa-se como signo de subversāo, isto é, como transgressiva por questionar os valores e a moral canônica, de modo a possibilitar leituras contra-hegemônicas, centradas nos desejos e no gozo das mulheres lésbicas, propondo, com isso, rasuras na "pornografia autoritária". Ao re(a)presentar o desejo lésbico e guei, Cassandra rejeita o "lugar" estereotipado de o homossexual como ser sombrio, sofredor, vítima passiva da sociedade, suas personagens "[..] sâo sujeitos resistentes tomando decisôes sob as restriçôes de um sistema de opressāo institucionalizada" (SANTOS, 2003. p. 26). Há nessa literatura uma transgressăo ctônica que resiste à realidade unidimensional, às representaçôes que constroem "um mundo verdadeiro das coisas de mentira", 9 limitado, circunscrito aos valores burgueses de cariz judaico-cristă. Uma das estratégias de imposiçăo da "pornografia autoritária" é matar as diferenças nas representaçōes. Nâo é à toa que o cânone literário, e o histórico também, focasse, quase que exclusivamente, no homem, branco, burguês, urbano, cis-heterossexual, ocidental e cristâo.

Por outro lado, ao contemplar uma figura feminina, o texto "As aventuras de Carmen Miranda", de Gilmar de Carvalho, publicado no n 6 do Lampiâo, de novembro de 1978, apresenta trechos da Carta-Testamento deixada por Getúlio Vargas para o povo brasileiro: 'Cada gota de meu sangue será uma chama imortal à vossa consciência que manterá a vibraçăo sagrada para a resistência" (CARVALHO, 1978, p. 16). Essas passagens sâo entrecruzadas por um poema que enaltece a figura da cantora: “Carmem Miranda urna glória nacional bis/ Carmem Miranda sambista sem rival/ Fez do nosso samba uma bandeira/ Embaixatriz da arte tropical/ Subiu desde logo na carreira/ Foi estrela universal." (CARVALHO, 1978, p. 16).

A emblemática figura da cantora mantém relaçăo direta com a história da homossexualidade masculina no Brasil no século XX, conforme destacou Green (2000):

9 "A arte é fonte privilegiada para o historiador interessado em resgatar nâo as verdades do acontecido, e sim as verdades do simbólico, expressas no imaginário de uma época. Este é o sentido daquilo que chamamos de mundo verdadeiro das coisas de mentira, para nos referirmos à traduçâo poética, literária ou pictórica da realidade." (PESAVENTO, 2002, p. 57). 
Em 1938, a cantora popular Carmen Miranda estrelava o filme brasileiro Banana da terra, como uma baiana que cantava e dançava com uma pequena cesta de frutas presa de forma precária à sua cabeça. Seu modo de atuar era uma imitaçáo exagerada das tradiçôes das mulheres afro-brasileiras dos mercados da Bahia. Logo depois, durante os quatro dias de festas do carnaval, centenas de homens tomaram as ruas do Rio de Janeiro. Vestidos com saias brancas rodadas e turbantes limpos e reluzentes, como faziam as famosas mulheres da Bahia, esses homens excederam a própria paródia da baiana encenada por Carmen Miranda (p. 21).

O texto resgata essa memória, das "[...] falsas baianas à la Carmen Miranda [que] engajaram-se numa subversâo festiva que arremedava tanto o comportamento sexual normativo quanto o tradicional hábito de travestir-se durante o carnaval" (GREEN, 200, p. 22). A cantora tornou-se símbolo internacional da cultura brasileira, tendo sua imagem extravagante recriada por gueis de todo o mundo. Carmen Miranda foi alçada ao posto de musa brasileira guei, de modo que se tornou expressáo de ambiguidade sexual, do camp ${ }^{10}$.

Entre os variados e inusitados recortes apresentados no texto, há um monólogo de um funcionário público do INSS, uma dessas falsas baianas à la Miranda engajada na subversăo festiva:

Chic mesmo é esse turbante escandaloso e esses quilos de balangandăs autênticos. Ah! os eternos problemas de uma maquilagem e essa barba podre cansa a minha beleza. Preciso fazer uma sobrancelhas super-finas e assim bem satânicas. E năo esquecer de treinar bem esses braços. Que tamancolas ridículas, ainda acabo saindo de sapato fanabor, morto de folclórico e bem barata (CARVALHO, 1978, p. 16).

Igualmente, a figura de Getúlio Vargas traz uma memória sobre a história da homossexualidade no Brasil. Foi durante o governo Vargas que a Polícia Civil, por meio do médico Leonídio Ribeiro, iniciou estudos antropológicos sobre homossexuais. Ribeiro procurou demonstrar as relaçôes entre a homossexualidade masculina e o mal-funcionamento endócrino ${ }^{11}$ :

As exigências políticas e administrativas do novo regime encabeçado por Getúlio Vargas facilitaram o estudo do comportamento 'desviante' nos moldes propostos por Lombroso e Marańón. Isso se deveu, em parte, à reorganizaçăo da polícia federal na capital do país, um elemento da estratégia global de Vargas para modernizar e centralizar o poder do governo, bem como controlar re-voltas trabalhistas e agitaçóes na classe baixa. (GREEN, 2000, p.251).

A subversăo manifesta-se por meio da tensâo entre a imagem recriada de Carmen Miranda, em referência à ambiguidade sexual, e a imagem de Vargas, em alusấo à

10 "Como comportamento, o camp pode ser comparada à fechaçăo, à atitude exagerada de certos homossexuais, ou simplesmente à afetaçăo. Já como questăo estética, o camp estaria mais na esfera do brega assumido, sem culpas, tâo presente nos exageros de muitos dos ícones da MPB". (LOPES, 2002, p. 95).

11 "Para realizar seu estudo em 1932, Ribeiro solicitou o apoio do Dr. Dulcídio Gonçalves, um oficial da polícia do Rio de Janeiro, que trouxe um 'precioso contingente' de 195 homossexuais 'profissionais' ao laboratório de Antropologia Criminal para serem fotografados e medi- dos, com o objetivo de determinar se havia alguma relaçăo entre sua sexualidade e sua aparência física" (GREEN, 2000, p.131). 
política estatal de produçáo da cis-hétero-norma, de maneira a produzir a reescritura ou a rasura: Getúlio Miranda ou Carmen Vargas. Vargas, entăo "responsável" por facilitar o estudo do comportamento desviante, é reescriturado na imagem da cantora, expressâo de ambiguidade sexual: "Carmen Miranda é musa do PTB ${ }^{12 "}$ ", finaliza.

Por fim, a última ediçâo do Lampiâo da Esquina do ano de 1978, publicada no mês de dezembro, trouxe trechos do romance $O$ beijo da mulher aranha, do escritor argentino Manuel Puig. Pelos segmentos publicados, é possível identificar um diálogo entre dois prisioneiros, Molina e Valentim. Năo fica claro, nesse fragmento, se Molina é uma travesti, visto que os trechos se alternam em designá-la como mulher e como homossexual. A narrativa foca na vivência amoroso-afetiva dos personagens. Os diálogos mostram a preocupaçấo de Valentim por Molina: "Entăo me escute, que em alguma coisa poderei ajudar. É questâo de falar. Antes de tudo tem que pensar em pertencer a um grupo, em năo ficar só." (PUIG, 1978, p. 16); o medo de Molina em ser separada do amante: "E do que tenho mais medo é de que nos separem e me ponham em outra cela e eu tique aqui para sempre, sabe lá com que otário." (PUIG, 1978, p.16). Os excertos re(a)presentam o cuidado entre os amantes: "quero que saia contente, e tenha boas recordaçôes de mim, como eu de você." (PUIG, 1978, p.16).

O romance foi publicado em 1976, período conturbado da história argentina cuja ditadura militar tinha acabado em 1973. Em 1976, porém, a direita engendrou um golpe para derrubar a presidente Isabel Perón. Em seu lugar, instalou-se uma junta militar, chefiada pelo general Jorge Rafael Videla. Durante o governo de Videla, opositores políticos foram presos, torturados e assassinados. A ditadura argentina também intensificou o dispositivo de produçâo que atuou sobre os sujeitos sexualmente dissidentes, com intuito de produzir năo apenas um corpo heterossexual, mas também um corpo cis. ${ }^{13} \mathrm{Na}$ narrativa literária em estudo, Valentim é preso político, marxista; Molina, preso por "corromper menores". A indeterminaçâo dos conceitos jurídicos justificou as inúmeras medidas persecutórias direcionadas aos sujeitos homossexuais, a exemplo de Molina. $\mathrm{O}$ encontro entre Molina e Valentim re(a)presenta um ato de resistência aos regimes cis-hétero-militares brasileiro e argentino. Diante dos horrores vividos na prisâo, Molina ousava encontrar afeto (e sexo) em outro homem; o gozo clandestino consegue resistir. Ironicamente, na prisáo em que é lançado por ser guei, Molina vivencia o amor marginal: "Valentin, você e mamăe săo as duas pessoas que eu mais quis no mundo." (PUIG, 1978, p.16).

Outra questâo levantada pelo texto é a perturbada relaçâo entre a esquerda marxista e as dissidências sexuais. Os militantes homossexuais, a exemplo de Joâo Silvério Trevisan (2000), James Green (2000) e Herbert Daniel (1982), relatam que a esquerda era homofóbica e via a homossexualidade como um desvio pequeno burguês, no caminho (im)posto pelos ideais maculados da Revoluçăo Russa a partir do golpe dado por Josef Stalin. As homossexualidades eram indesejadas, nos grupos de esquerda, em razăo de entenderem que năo passava de um desbunde, năo condizente com a masculinidade revolucionária, conforme o arquétipo viril de Che Guevara - masculinidade

12 O Partido Trabalhista Brasileiro - PTB foi fundado por Getúlio Vargas em 1945.

13 Afirmamos isso com base na leitura de Rapisardi e Modarelli (2001) sobre as vivências clandestinas dos homossexuais argentinos diante da ditadura militar (1976-1983). 
revolucionária (GREEN, 2012). O encontro entre Molina e Valentim re(a)presenta também um ato de resistência à esquerda homofóbica brasileira e argentina.

Quando o Lampiâo trouxe, em sua coluna literária, personagens cujas vivências, bem como as condutas e práticas, os prazeres e desejos tensionaram a produçáo cis-heteronormativa, questionou e afrontou a legitimidade moral imposta pelo regime ditatorial. A literatura lampiônica inaugurou uma autêntica resistência à cis-hétero- ditadura por meio da poesia, do erótico, da imagem, da magia, dos afetos, dos desejos, dos sonhos, do sexo, da crueza da vergonha. No domínio da sexualidade, da moral e dos bons costumes, a literatura homoerótica publicada no jornal mostrou que a, por nós denominada, cis-hétero-realidade náo passa de um conjunto de ficçôes apresentadas como naturais, que castram prazeres e gozos, limitando nossa capacidade de sonhar. Os textos analisados sinalizam que a naturalizaçáo da cis-heterossexualidade em desfavor da "anomalia" homossexual foi desenvolvida por mecanismos e estratégias estruturadas a partir de relaçóes de poder, que buscam capturar as práticas sexuais estruturadas em desacordo com a cis-hétero-norma.

A pornografia autoritária do regime aparece como construçăo de uma fantasia perfeita que impóe o Um, resistindo a qualquer tipo de diferença. Para Luis Alberto Warat (1988), a pornografia procura ansiosamente um princípio unitário. Pornográfico é o regime que castra as possibilidades de sonhar, amputando a multiplicidade de transformaçōes. O regime cis-hétero-ditatorial brasileiro foi a tentativa mais acabada de impor um território específico e limitado de ficçōes como verdade inquestionável - a verdade do sexo, da religiâo, da burguesia - à qual todos, sem exceçóes, deveriam se submeter. Nesse sentido, entendemos que a ditadura foi pornográfica, constituindo-se como tentativa de castrar as possibilidades do vir a ser, e que escapa, no mais das vezes, aos padrôes impostos como universais.

Por isso, reforçamos a sustentaçâo da existência de um dimensâo cis-hétero-ditatorial no regime militar brasileiro de 1964, marcada pela tentativa de univocidade do sexo a partir da intensificaçáo do cis-hétero-corpo em torno da família nuclear burguesa e dos valores judaico-cristăos. Indícios históricos permitem afirmar que o governo militar impôs um conjunto de ficçôes morais, religiosas e políticas como única possibilidade de leitura e interpretaçâo do mundo. A verdade era apenas uma: a cis-hétero-realidade como parâmetro de vida tradicional, espelhando-se nos dogmas e valores da classe burguesa e cristă que, quase sem exceçóes, apoiou e geriu o golpe na entăo recente democracia brasileira.

Nesse sentido, a literatura lampiônica foi erótica ${ }^{14}$, isto é, exibiu a pluralidade da existência através do questionamento das formas oficiais de cultura, problematizando as diferenças que năo querem ser aceitas ou assimiladas, muito menos toleradas, num iminente caráter transgressivo. Warat (1988) entende que o erotismo assume a complexidade da vida em suas contradiçōes plurais, sem tentar domesticá-la, reduzi-la, amputá-la. O erotismo lampiônico nada mais foi do que uma luta empreendida contra a realidade sexual imposta pelo regime, devolvendo Eros à vida, demonstrando que

14 Erótico aqui é tomado como questionamento da realidade imposta como princípio de unidade, conforme Warat (1988). 
é possível viver o extraordinário, de modo que o sublime se prolifere no cotidiano. ${ }^{15}$ Ao questionar a pornografia autoritária, o Lampiâo se constituiu como um transgressivo gesto político de resistência à política sexual do regime militar, desenhando no espectro visível, em cores quentes e vibrantes, trajetórias e deslocamentos de corpos e sexualidades múltiplas, instáveis, subterrâneas e revolucionárias (numa dimensāo talvez inalcançável ao mais vanguardista movimento de esquerda). À margem do que o governo autoritário apontava, os textos analisados indicam que o periódico em estudo se opôs à excessiva formalizaçấo, ao dualismo esquemático e à razăo instrumental, rompendo, assim, com a referência única - o homem, branco, heterossexual, urbano, burguês, cristăo - para re(a)presentar uma estética das diferenças, uma ética da estética ${ }^{16}$ homossocial, indesejada no regime por năo reproduzir os valores morais da "família tradicional".

Essa literatura ctônica resistiu aos sentidos solidificados do imaginário instituído, rasurando a clausura uniforme e seriada imposta ao sexo. O Lampiāo re(a)presentou os desejos, práticas, prazeres, sofrimentos, dores, castraçōes, limitaçôes, emoçôes de gueis, lésbicas e travestis, para além da mera representaçăo da vitimizaçāo, assumindo, com isso, um destacado papel no ativismo homossexual. A literatura lampiônica năo representa vítimas de uma sociedade lesbo-trans-homofóbica, mas re(a)presenta a resistência homoerótica ao regime cis-hétero-militar, nâo se restringindo, assim, aos padróes de uma cultura cis-heterossexual burgo-militar, circunscrita aos valores monolíticos judaico-cristăos.

O jornal constituiu-se como uma experiência singular de oposiçâo ao sistema ditatorial brasileiro, em específico, à moral e aos bons costumes, afervorados pelos defensores do regime de exceçăo. Nesse sentido, faz-se oportuno destacar que Norberto Bobbio (2004) distingue a resistência da contestaçăo, adotando, para isso, o critério da referência ao seu respectivo contrário: a obediência é o contrário da resistência, o contrário da contestaçăo é a aceitaçăo. Há uma leve, mas importante, diferença entre a obediência a uma norma ou ao ordenamento e sua aceitaçấo. Enquanto obedecer é uma atitude passiva, aceitar é ativa: "[...] implica, se nâo um juízo de aprovaçâo, pelo menos uma inclinaçăo favorável a se servir da norma ou das normas para guiar a própria conduta e para condenar a conduta de quem nâo se conforma com ela ou elas" (BOBBIO, 2004, p.61).

Resistir consiste em todo comportamento de ruptura contra a ordem estabelecida, (im)posta. $O$ ato de resistência póe em crise o sistema pela sua mera produçăo, "mas năo necessariamente em questăo" (BOBBIO, 2004, p. 61). Assim, a literatura lampiônica é tanto um comportamento de ruptura contra a ordem sexual imposta pelo regime cis-hétero-militar, como também um espaço de contestaçăo que, para Bobbio (2004), vai além de um comportamento de ruptura: refere-se a uma atitude crítica que póe a ordem estabelecida em questāo, sem necessariamente colocá-la em crise. A contestaçâo

15 "Nesse movimento de trazer à tona a homossexualidade no espaço social e fazer que esses indivíduos fossem reconhecidos enquanto cidadăos, que a ediçăo de número zero do jornal trouxe o editorial como título 'Saindo do gueto' que propôs a açăo de tirar os homossexuais da marginalidade." (AMARAL; BERTOLLI, 2015, p. 61).

16 Michel Maffesoli (1996) aponta a ética da estética como dimensâo coletiva da vida cotidiana, sendo o fundamento do vínculo societal, é caracterizada pela valorizaçâo da alteridade e afetividade entre pessoas e grupos nas sociedades pós-modernas. 
atinge mais do que os subsistemas político e jurídico, abrangendo modelos culturais gerais, tensionando a legitimidade profunda que assegura os subsistemas político e jurídico.

\section{E O LAMPIÃO? SEGUIU ACESO NAS ESQUINAS DO BRASIL?}

A literatura homoerótica publicada no Lampiāo da Esquina resistiu à "pornografia autoritária", à unidade sexual intensificada pelo regime cis-hétero-militar, marcando profundamente a metamorfose do vínculo social, caracterizada pela saturaçáo da identidade, do princípio do Um. A homossocialidade presente nas páginas literárias do referido jornal, aqui analisadas, trouxe de volta, eroticamente, a importância do sentir-se pertencente a um lugar, a um grupo, potencializando, com isso, o estar-junto para regozijar-se nos prazeres e nos sofrimentos mundanos. A resistência lampiônica manifestou a revanche do "dionisíaco", da fugacidade do vínculo social. Enquanto espaço democrático de resistência, o periódico foi uma declaraçăo de guerra à moral e aos bons costumes judaico-cristăos.

Por intermédio da literatura homoerótica, o Lampiāo operou um deslocamento da homogeneidade para a heterogeneidade do real, do pornográfico para o erótico, resistindo à hiper-realidade totalitária. Dessa forma, potencializou o tribalismo de conotaçăo homossocial, constituído por pessoas que se identificam por meio de rituais, elementos de cultura, valores, moda, estilo, sentimentos, emoçōes, sofrimentos, medos, angústias e que, mediante essa socialidade, contestam e resistem ao individualismo e à identidade (MAFFESOLI,1987).

Entendida para além das práticas sexuais entre sujeitos do mesmo sexo, compreendendo atitudes, gestos, afetos, sensibilidade, sentimentos, emoçóes, linguagem corporal, que infringem as normas rígidas pré-estabelecidas como masculinas ou transitem entre o masculino e feminino, a homossocialidade lampiônica foi lida como imoral, uma afronta à ordem "democrática" cristă. Trata-se do sentimento de pertencimento a um lugar ou grupo que permite a cada um sentir-se deste mundo e entrar em contato com o outro de um modo natural, sem apagamento da história e singularidades do sujeito. Ainda, vem a ser a fugacidade do presente, o eterno retorno, as expressóes, os afetos, as emoçōes, os medos, as angústias, a vergonha, vivenciados por sujeitos homoeroticamente inclinados, em seu constante processo de produçăo em torno da cis-hétero-norma.

O Lampiāo foi, dessa forma, "[...] a batalha do sujeito pelo direito de se colocar, de năo aceitar a coerçâo, é a batalha por um lugar no qual o sujeito se encontre um poder de dizer, com ou sem respaldo da hierarquia" (LAGAZZI, 1988). Trata-se da potência societal sobre a qual nos fala Maffesoli (2012), uma "força interna precedente e fundante do poder em suas diversas formas" (p. 12). Excitados, vemos uma homossocialidade ctônica, tribal nas páginas literárias do Lampiâo.

A literatura publicada nesse jornal aponta, nâo para uma concepçăo de tempo linear ou cíclico, mas sim, para um tempo pontilhista ${ }^{17}$ : os pontos aparecem e se conectam

17 A noçấo de tempo pontilhista é desenvolvida por Michel Maffesoli (2003) e retomada por Zygmunt Bauman (2008): "Tal como experimentado por seus membros, o tempo na sociedade moderna nâo é 
com nosso passado e futuro, presentificando-os. O tempo é uma sucessăo de presentes, re(a)presenta rupturas e descontinuidades. Essa transformaçăo sobre a percepçáo do tempo mostra que o fascismo năo ficou no nosso passado; queríamos que assim fosse. O fascismo é eterno porque se presentifica por meios dos pontos temporais que nos conectam ao passado e se projetam como futuro. No entanto, o fascismo sempre será presente, ao menos em potência: "pode voltar sob as vestes mais inocentes. Nosso dever é desmascará-lo e apontar o indicador para cada uma de suas novas formas - a cada dia, em cada lugar do mundo (ECO, 2002, p. 10). Também pode trajar-se com vestes civis, e tem mostrado que convive bem com nosso sistema semidemocrático eleitoral. O tempo pontilhista mostra, da mesma forma, que o fogo lampiônico năo ficou preso no passado, mas comparece no presente para resistir e lembrar que "vencereis pero no convencereis" ${ }^{\prime \prime}$.

É o eterno retorno do direito de sonhar, de năo aceitar esquecer, nos tempos de "amnésia obrigatória", de contestar a "pornografia autoritária" - El derecho al delírio como diz Eduardo Galeano (1998). Aí está a transgressăo lampiônica, que nos permitiu sonhar, delirar concretamente a partir da resistência homoerótica e mostrou que "A perfeiçâo seguirá sendo o privilégio tedioso dos deuses, mas neste mundo, neste mundo avacalhado e maldito, cada noite será vivida como se fosse a última e cada dia como se fosse o primeiro" (GALEANO, 1998, p. 34).

\section{REFERÊNCIAS}

AFONSO-ROCHA, Ricardo. Bichas inauguram a utopia. Trabalho de conclusăo de curso - (Bacharelado Em direito). Universidade Estadual de Santa Cruz, Ilhéus, Bahia, 2018.

AGAMBEN, G. Homo Sacer: o poder soberano e a vida nua. Belo Horizonte: Editora da UFMG, 2007.

AGAMBEN, G. O que é um dispositivo? Outra Travessia, n. 5, p. 9-16, 2005.

AMARAL, M; BERTOLLI, C. Qual é o crime desse rapaz?": resistência e discurso no jornal Lampiāo da Esquina. Estudos em Comunicaçâo, Săo Paulo, v. 18, n. 2, p. 53-76. 2015.

AUGUSTO, P. Na pensâo a flor de Minas. Lampiāo da Esquina. Rio de Janeiro, n 0, abr. 1978, Seçăo literária.

BAUMAN, Z. Vida para consumo: a transformaçăo das pessoas em mercadoria. Zahar, 2008.

cíclico nem linear como costumava ser para os membros de outras sociedades. Em vez disso, para usar a metáfora de Michael Maffesoli, é 'pontilhista', um tempo pontuado, marcado (senáo mais) pela profusâo de rupturas e descontinuidades... A vida, seja individual ou social, nâo passa de uma sucessâo de presentes, uma coleçâo de momentos experimentados em intensidades variadas." (p. 36).

18 Famosa frase dita por Miguel de Unamuno a José Millán-Astray, general franquista (PEDRÓS GASCÓN, 2007). 
BENTO, B. Dispositivo de resistência. In: .Transviad@s: gênero, sexualidade e direitos humanos. EDUFBA, 2017.

BENTO, B. Necrobiopoder: Quem pode habitar o Estado-naçăo? Cadernos Pagu, n. 53, 2018.

BOBBIO, N. Era dos direitos. Elsevier Brasil, 2004.

BRASIL. Comissâo Nacional da Verdade. Ditadura e homossexualidades/Comissâo Nacional da Verdade. Brasília: CNV, 2014.

BRASIL. Constituiçâo (1946). Constituiçāo da República Federativa do Brasil. Brasília, DF: Senado Federal: Centro Gráfico, 1946.

CABANAAS, Tereza. A poesia marginal e os novos impasses da comunicaçăo poética. Revista de Letras, v. 45, n. 1, p. 89-116, 2005.

CARVALHO, G. de. As aventuras de Carmen Miranda. Lampiâo da Esquina. Rio de Janeiro, n 5, nov. 1978, Seção literária, p. 16.

CASTILLO, A. O maricas. Lampiâo da Esquina. Rio de Janeiro, n 3, ago. 1978, Seçăo literária, p. 16.

CHARTIER, R. Defesa e ilustraçăo da noçăo de representaçăo. Fronteiras, v. 13, n. 24, p. 15-29, 2011.

COLAÇO, R. De Daniele a Chrysóstomo: quando travestis, bonecas e homossexuais entram em cena. 2012. 2012. Tese de Doutorado. Tese (Doutorado em História)-Universidade Federal Fluminense, Rio de Janeiro.

COWAN, B. Homossexualidade, ideologia e subversāo no regime militar. In: GREEN, J; QUINALHA, R. (org.). Ditadura e homossexualidades: repressâo, resistência e a busca da verdade. Săo Carlos: EduFSCar, 2015. p. 27-52.

DANIEL, H. Passagem para o próximo sonho: um possível romance autocrítico. Editora Codecri, 1982.

ECO, U. O Fascismo Eterno. In: . Cinco escritos morais. Rio de Janeiro: Record, 2002

FERNANDES, M. Lésbicas e a ditadura militar: uma luta contra a opressâo e por liberdade. In: GREEN, J.; QUINALHA, R. Ditadura e homossexualidades: repressāo, resistência e a busca da verdade. Sâo Paulo: Editora UFSCar, 2015. 
FERNANDES, M. Lésbicas e ditadura militar: uma luta contra opressăo e por liberdade. In: GREEN, J; QUINALHA, R. (org.). Ditadura e homossexualidades: repressâo, resistência e a busca da verdade. Sáo Carlos: EduFSCar, 2015. p.125-148.

FICO, C. Além do golpe: versôes e controvérsias sobre 1964 e a ditadura militar. Rio de Janeiro: Record, 2004.

FOUCAULT, M. A ordem do discurso: aula inaugural no College de France, pronunciada em 2 de dezembro de 1970. 4.ed. Sáo Paulo: Loyola, 1998.

FOUCAULT, M. História da Sexualidade 1: a vontade de saber. Rio de Janeiro: Paz e Terra, 2017.

FOUCAULT, M. O corpo utópico, as heterotopias. Săo Paulo: n-1 Ediçōes, 2013.

GALEANO, E. El derecho al delirio. In: GALEANO, E. Patas arriba: la escuela del mundo al revés. Madrid: Siglo XXI, 1998.

GINZBURG, C. Sinais: raízes de um paradigma indiciário. In: Mitos, emblemas, sinais. Săo Paulo: Companhia das Letras, 1990, p. 143-179.

GREEN, J. Além do carnaval: a homossexualidade masculina no Brasil do século XX. Săo Paulo: UNESP, 2000.

GREEN, J. Quem é o macho que quer me matar? Homossexualidade masculina, masculinidade revolucionária e luta armada brasileira dos anos 1960 e 1970. Revista Anistia Política e Justiça de Transiçâo, Brasília: Ministério da Justiça, p. 58-93, 2012.

HILÁRIO, P. A dona boazuda. Lampiâo da Esquina. Rio de Janeiro, n 4, out. 1978, Seçâo literária, p. 16.

JORGE, F. Antropofagia. Lampiâo da Esquina. Rio de Janeiro, nº 0, abr. 1978, Seçăo literária.

LAGAZZI, S. O desafio de dizer nâo. Campinas, SP: Pontes, 1988.

LAMPIĀO DA ESQUINA. Direçăo de Lívia Perez. Rio de Janeiro: Produçăo Independente, 2016, documentário.

LAMPIĀO DA ESQUINA. Rio de Janeiro, n² 1, abr. 1978.

LOPES, D. O homem que amava rapazes e outros ensaios. Rio de Janeiro: Aeroplano, 2002. 
MAFFESOLI, M. Elogio da razāo sensível. Petrópolis: Vozes, 1998

MAFFESOLI, M. Homossociabilidade: da identidade às identificaçōes. Bagoas Revista de Estudos Gays e Lésbicos, Natal, v.1, n.1, p. 15-26, 2012.

MAFFESOLI, M. No fundo das aparências. Petrópolis: Vozes, 1996.

MAFFESOLI, M. O instante eterno. Săo Paulo: Zouk, 2003.

MAFFESOLI, M. O tempo das tribos: o declínio do individualismo nas sociedades de massa. Săo Paulo: Forense-Universitária, 1987.

MAFFESOLI, Michel. O imaginário é uma realidade. Revista Famecos, v. 8, n. 15, p. 74-82, 2001.

MBEMBE, A. Necropolítica: biopoder, soberania, estado de exceçăo, política da morte. Traduçăo de Renata Santini. Săo Paulo: n-1 ediçôes, 2018.

MíCCOLIS, L. O poema para teus seios. Lampiāo da Esquina. Rio de Janeiro, nº 0, abr. 1978, Seçăo literária.

MORANDO, L. Por baixo dos panos: repressâo a gays e travestis em Belo Horizonte (19631969). In: GREEN, J; QUINALHA, R. (org.). Ditadura e homossexualidades: repressâo, resistência e a busca da verdade. Săo Carlos: EduFSCar, 2015, p. 53-82.

MORANDO, L. Por baixo dos panos: repressáo a gays e travestis em Belo Horizonte (1963-1969). In: GREEN, J.; QUINALHA, R. Ditadura e homossexualidades: repressâo, resistência e a busca da verdade. São Paulo: Editora UFSCar, 2015.

MOURA, M. de. Aniversário. Lampiāo da Esquina. Rio de Janeiro, nº 0, abr. 1978, Seçâo literária, p. 16.

NIETZSCHE, F. Onascimento da tragédia: ou helenismo e pessimismo. Editora Companhia das Letras, 2007.

PAGLIA, C. Personas sexuais: arte e decadência de Nefertite a Emily Dickinson. Companhia das Letras, 1990.

PEDRÓS GASCÓN, A. F. España, laberinto de soledades: latinoamericanización del imaginario nacional en" Tiempo de silencio" y" Reivindicación del conde don Julián". España contemporánea: Revista de literatura y cultura, Barcelona, v. 20, n. 1, p. 39-62, 2007.

PEREIRA, P. Queer decolonial: quando as teorias viajam. Revista Semestral do Departamento e do Programa de Pós-Graduaçâo em Sociologia da UFSCar, v. 5, n. 2, p. 411, 2015. 
PESAVENTO, S. Este mundo verdadeiro das coisas de mentira: entre a arte e a história. Revista Estudos Históricos, Sáo Paulo, v. 2, n. 30, p. 56-75, 2002.

PESAVENTO, S. História e história cultural. Autêntica, 2013.

PUIG, M. Trechos do romance O beijo da mulher aranha. Lampiāo da Esquina. Rio de Janeiro, nº 6, dez. 1978, Seçâo literária, p. 16.

QUINALHA, R. Contra a moral e os bons costumes: a política sexual da ditadura brasileira (1964-1988). 2017. Tese (Doutorado em Relaçôes Internacionais) - Instituto de Relaçôes Internacionais, Universidade de Sáo Paulo, Săo Paulo, 2017.

RAPISARDI, F; MODARELLI, A. Fiestas, baños y exilios: los gays porteños en la última dictadura. Buenos Aires: Sudamericana, 2001.

RICOEUR, P. Tempo e narrativa: 2. A configuraçăo do tempo na narrativa de ficçăo. Martins Fontes, 2010.

RIO DE JANEIRO. Comissâo Estadual da Verdade. Ditadura e homossexualidades/ Comissâo Estadual da Verdade. Rio de Janeiro: CEVRJ, 2015.

RIOS, C. A hora do amor. Lampiâo da Esquina. Rio de Janeiro, nº 5, nov. 1978, Seçâo literária, p. 16.

ROCHA, M. Do outro lado da porta. Lampiāo da Esquina. Rio de Janeiro, n² 2, maio 1978, Seçâo literária, p. 16.

RODRIGUES, J. Um Lampiăo iluminando esquinas escuras da ditadura. In: GREEN, J; QUINALHA, R. (org.). Ditadura e homossexualidades: repressăo, resistência e a busca da verdade. Săo Carlos: EduFSCar, 2015, p. 83-124.

ROIG, A. Nem todos os parques săo um paraíso. Lampiāo da Esquina, Rio de Janeiro, $\mathrm{n}^{\circ} 1$, abr. 1978, Seção literária, p. 16.

SANTOS, R. Cassandra Rios e o surgimento da literatura gay e lésbica no Brasil. Revista Gênero, v. 4, n. 1, 2012.

SÂO PAULO. Comissāo Estadual da Verdade Rubens Paiva. Ditadura e homossexualidades/Comissāo Estadual da Verdade Rubens Paiva. Sáo Paulo: CEVSP, 2015.

SCOTSON, J. L.; ELIAS, N. Os estabelecidos e os outsiders: sociologia das relaçōes de poder a partir de uma pequena comunidade. Rio de Janeiro: Jorge Zahar, 2000. 
TEMPORADA DE CAÇA. Direçăo de Rita Moreira. Săo Paulo: produçáo independente, 1988, documentário.

TREVISAN, J. S. Devassos no paraíso: A homossexualidade no Brasil, da colônia à atualidade. Rio de Janeiro: Record, 2000.

WARAT, L. A. Manifesto do surrealismo jurídico. Santa Catarina: Acadêmica, 1988. 